\title{
Ardahan Üniversitesi Yenisey Kampüsü'nde Görev Yapan Personel ve Öğrenim Gören Öğrencilerin Su Ayak İzinin Belirlenmesi
}

\author{
Nesrin DURSUN ${ }^{1,2 *}$ (D) \\ ${ }^{1}$ Ardahan Üniversitesi, Mühendislik Fakültesi, Çevre Mühendisliği Bölümü, Ardahan, Türkiye \\ ${ }^{2}$ Ardahan Üniversitesi, Merkezi Araştırma Laboratuvarı Uygulama ve Araştırma Merkezi, Ardahan, Türkiye
}

Geliş / Received: 4.07.2019, Kabul / Accepted: 15.12.2019

\begin{abstract}
$\ddot{\mathbf{O z}}$
Son yıllarda, tatlı su talebinde artış olmuştur. Nüfus artışı, yaşam standartlarını iyileştirme, tüketim modellerini değiştirme, sulanan tarımsal alanların genişlemesi v.s. tatlı su talebi artışının nedenleri olarak sıralanabilir. Küresel ölçekte su kullanımı, çoğunlukla tarımsal üretimle olup bununla birlikte endüstriyel ve evsel alanlarda tüketilen ve kirlenen önemli derecede su miktarıyla gerçekleşmektedir. Arjen Y. Hoekstra, tedarik zinciri boyunca su tüketimini göz önünde bulundurmuş ve "su ayak izi" kavramının ortaya çıkmasını sağlamıştır. Su ayak izi, bir tüketicinin veya üreticinin hem doğrudan hem de dolaylı su kullanımını gözeten tatlı su tüketiminin bir göstergesidir. Su ayak izini değerlendirmede genel amaç, insan faaliyetlerinin veya belirli ürünlerin su kıtlığı ve kirliliği ile ilgili olduğunu, faaliyetlerin ve ürünlerin su perspektifinden nasıl daha sürdürülebilir hale gelebileceğini analiz etmektir. Bu çalışma, Ardahan Üniversitesi Yenisey Kampüsü'nde her birimde eşit sayıda personel ve öğrenci katılımı dikkate alınarak uygulanmıştır. Kampüste görev yapan 160 personel ve öğrenim gören 160 öğrenci olmak üzere toplam 320 kişiye "Su Ayak İzi Ağı (Water Footprint Network-WFN)"ndaki sorular yöneltilerek, kişisel tüketim davranışlarına bağlı olarak kampüsün su ayak izinin belirlenmesi hedeflenmiştir. Su ayak İzi Ağı'na göre personelin su ayak izi ortalama $1420.4 \mathrm{~m}^{3} / \mathrm{y} 1$, öğrencilerin su ayak izi ortalama $1490.1 \mathrm{~m}^{3} / \mathrm{y} 1$, toplam su ayak izi ise ortalama $1455.2 \mathrm{~m}^{3} / \mathrm{y} 1 \mathrm{l}$ olarak belirlenmiştir.
\end{abstract}

Anahtar Kelimeler: Su Ayak İzi, Sürdürülebilirlik, Yenisey Kampüsü, Ardahan

\section{Determination of the Water Footprint of the Staff and Students at Yenisey Campus of Ardahan University}

\begin{abstract}
Demand for freshwater has increased in recent years. Population growth, improvement in living standards, change in consumption patterns, expansion of irrigated agricultural areas, etc. can be listed as the reasons for the increase in fresh water demand. Water use on a global scale is mostly associated with agricultural production, however, industrial and domestic areas consume and pollute a significant amount of water, too. Arjen Y. Hoekstra considered water consumption throughout the supply chain and created the concept of "water footprint". The water footprint is an indicator of freshwater consumption that looks at both direct and indirect water use of a consumer or producer. The overall objective in assessing the water footprint is to analyse the relation of human activities or certain products with water scarcity and pollution, and how activities and products can become more sustainable from a water perspective. This study was conducted by taking into consideration an equal number of staff and students in each unit at Yenisey Campus of Ardahan University. The study aimed to determine the water footprint of the campus in relation to personal consumption behaviours by asking the questions in the "Water Footprint Network (WFN)" to a total of 320 people at the campus, including 160 from both the staff and the students. According to the Water Footprint Network, the average water footprint of the staff was determined as $1420.4 \mathrm{~m}^{3} /$ year and of the students as $1490.1 \mathrm{~m}^{3} /$ year, and in total, the average was $1455.2 \mathrm{~m}^{3} /$ year.
\end{abstract}

Keywords: Water footprint, Sustainability, Yenisey Campus, Ardahan 


\section{Giriş}

Son y1llarda, başta insan faaliyetleri olmak üzere çevresel değişimlerden kaynaklanan tatlı su kıtlığ 1 nedeniyle su talebinde artış olmuştur. Su kıtlığı, doğrudan ve dolaylı su tüketiminde artış ve sınırlı su tedariki nedeniyle toplumun sürdürülebilir kalkınmasını etkileyen küresel bir tehdit haline gelmiştir. İnsan faaliyetleri ile fazla miktarda su tüketilmekte dolayısıyla su kirliliği oluşmaktadır. Su talebi artışının nedenleri; dünya nüfusu artışı, yaşam standartlarını iyileştirmek, ekonomik büyümeye bağlı olarak tüketim modellerini değiştirmek ve sulanan tarımsal alanların genişlemesi olarak sıralanabilir. Ekonomik büyüme, su ayak izi değeri yüksek olan gıda ürünlerinin kişi başına tüketimini etkileyerek daha fazla su talebine neden olmaktadır. Dünyadaki su tüketiminin büyük çoğunluğu tarımsal ürün talebinden kaynaklanmaktadır. Çevresel değişimler ve kentleşme, su kaynaklarının tarımsal üretim sistemlerinde kullanımını etkilemektedir (Hoekstra ve Mekonnen, 2012; Vörösmarty vd., 2000; Schewe vd., 2014; Mekonnen ve Hoekstra, 2016; Cao vd., 2018a; Cao vd., 2018b; Renault ve Wallender, 2000). Küresel ölçekte su kullanımı, çoğunlukla tarımsal üretimle olup bununla birlikte endüstriyel ve evsel alanlarda tüketilen ve kirlenen önemli derecede su miktarıyla gerçekleşmektedir. Su tüketimi ve kirliliği; sulama, banyo, yıkama, temizleme, soğutma ve işleme gibi spesifik faaliyetlerle ilişkilendirilebilir (Hoekstra vd., 2011). Son yıllarda popüler olan "Su ayak izi" kavramı yani tedarik zinciri boyunca su tüketimini göz önünde bulundurma görüşü, 2002 yılında UNESCO-IHE Su Eğitimi Enstitüsü'nde çalışan Arjen Y. Hoekstra tarafindan oluşturulmuştur. Twente Üniversitesi'nde 2008 y1lında su yönetimi profesörü olan Hoekstra öncülügünde akademisyenler, iş dünyası, sivil toplum kuruluşları ile birlikte sürdürülemez su kullanımının zorluklarının üstesinden gelebilmek için $\mathrm{Su}$ Ayak İzi Ağ̀ (Water Footprint Network-WFN) kurularak, literatüre kazandırılmıştır.

Su ayak izi, bir tüketicinin veya üreticinin sadece doğrudan tatlı su kullanımı olmamakta aynı zamanda dolaylı tatlı su kullanımının da bir göstergesidir. Böylece su ayak izi, bir tüketicinin veya üreticinin veya iş alanının tatlı su sistemlerini kullanımıyla ilgili olarak daha iyi ve geniş bir perspektif sunmaktadır. Doğrudan su ayak izi, tüketicilerin ve iş alanlarının geleneksel odak noktası olmasına rağmen, dolaylı su ayak izi genellikle daha büyüktür. Tüketiciler, yalnızca doğrudan su ayak izlerini ele alarak su ayak izlerinin en büyük kısmının, evde tükettikleri su ile ilişkili olduğunu düşünmekte, süpermarkette veya başka tüketim alanlarında aldıkları ürünlerle ilişkili olduğunu ihmal etmektedir. Su ayak izi, hacimsel su tüketimi ve kirlilik ölçütü olup, su tüketimi ve kirliliğin lokal çevresel etkisinin önemli bir ölçütü olmamaktadır. Belirli miktarda su tüketimi ve kirliliğinin lokal çevresel etkisi, lokal su sistemlerinin yararlanabilirliğine ve aynı sistemi kullanan su tüketicileri ve kirleticilerinin sayısına bağlıdır. $\mathrm{Su}$ ayak izi hesapları, insanlar tarafından çeşitli amaçlarla suyun kullanımının nasıl tahsis edildiğine dair hem zamana hem mekana ait açıkça bilgi verebilir. Sürdürülebilir eşit su kullanımı ve tahsisi hususunda tartışmaları besleyebilir. Ayrıca çevresel, sosyal ve ekonomik etkilerin lokal değerlendirmesi için iyi bir temel oluşturabilir (Hoekstra vd., 2011).

"Su Ayak İzi Ağı" Hoekstra vd. (2011) tarafından tanımlanmış olup, su ayak izi yöntemi için küresel bir standart olarak görülmüştür. $\mathrm{Bu}$ standart incelenen ürün, 
proses veya hizmet için gerekli olan tüm doğrudan ve dolaylı su kullanımlarını kapsayacak şekilde su kullanımını tanımlamaktadır. Su ayak izi yeşil, mavi ve gri olarak Şekil 1'de sunulduğu üzere üç bileşenden oluşmaktadır. Yeşil su ayak izi, yağmur suyu tüketimini belirterek; özellikle mahsul üretimi ile ilgilidir. Mavi su ayak izi, yüzey ve yeraltı suyu kaynaklarının tüketimini ifade ederek; buharlaşan veya başka bir su toplama alanına dönüşü olan veya bir ürüne eklenerek tüketilen su hacmi olarak tanımlanır. Mavi su ayak izi çoğu kez su çekilmesinden daha küçüktür, çünkü su çekilmesiyle bir kısmı yeraltı veya yüzey suyuna genellikle dönebilir. Gri su ayak izi, tatlı su kirliliği derecesinin bir göstergesidir ve mevcut ortam suyu kalitesi standartlarına göre kirletici yükünün bertaraf edilmesi yada azaltılması için gerekli tatlı su hacmi olarak tanımlanır (Hoekstra ve Mekonnen, 2012). Su ayak izini değerlendirmede genel amaç, insan faaliyetlerinin veya belirli ürünlerin su kıtlığ ve kirliliği ile ilgili olduğunu, faaliyetlerin ve ürünlerin su perspektifinden nasıl daha sürdürülebilir hale gelebileceğini analiz etmektir.

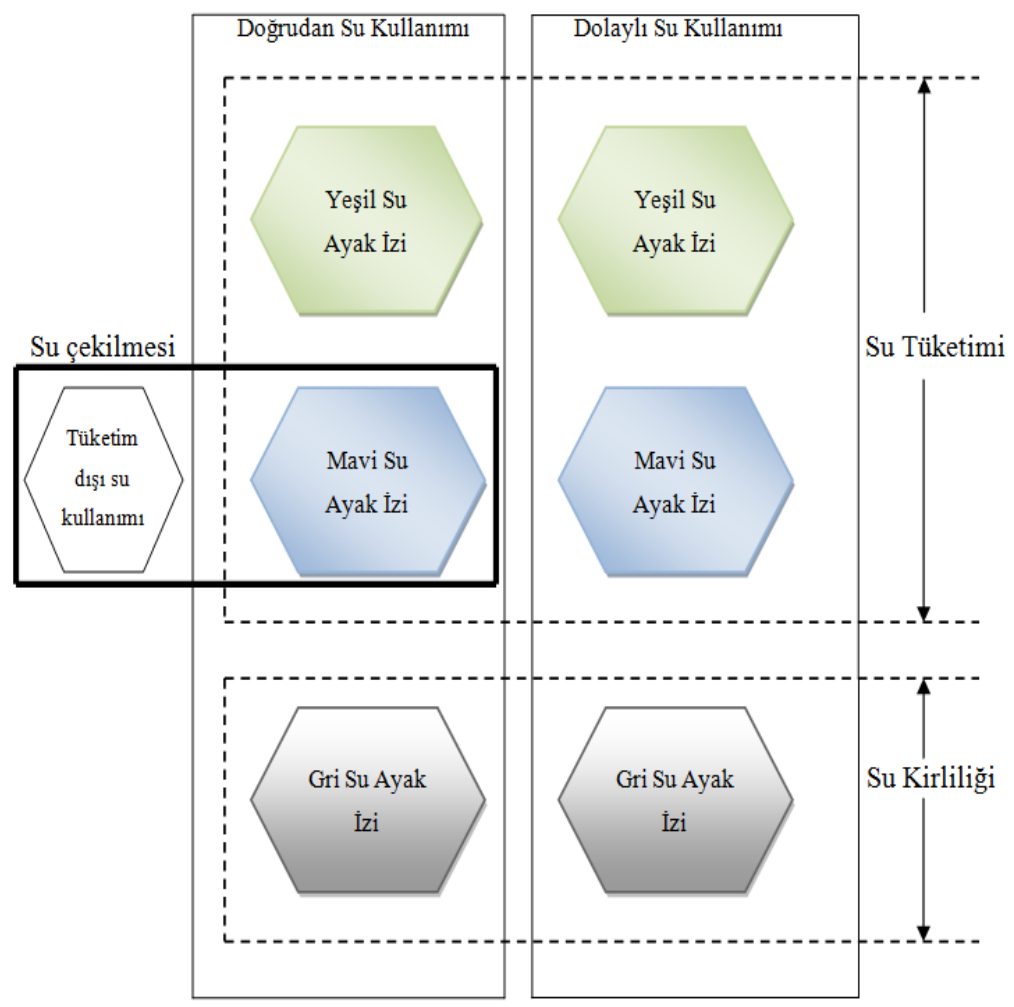

Şekil 1. Su ayak izi bileşenleri (Hoekstra vd., 2011)

\section{Su Ayak İzi Ăğ Uygulaması}

Ardahan Üniversitesi Yenisey Kampüsü, personel ve öğrencilerine su ayak izini belirlemek amacıyla gıda tüketimi, evsel su kullanımı ve endüstriyel ürün tüketimi olmak üzere üç alana yönelik kişisel tüketim alışkanlıklarıyla ilgili Su Ayak İzi Ağı soruları yöneltilmiştir. Belirlenmiş sayıda personel (akademik, idari ve diğer) grubuna ve öğrenci (fakülteler, yüksekokullar) grubuna ă̆ soruları yüz yüze yöneltilerek her birimden eşit katılım ile su ayak izinin belirlenmesine dair ortalama sonuçlar elde edilmesi 
hedeflenmiştir. 160 personel ve 160 öğrenci olmak üzere toplam 320 kişiye uygulanmış olan tüketim alışkanlıkları bilgisini veren $\mathrm{Su}$ Ayak İzi Ağı soruları Tablo 1'de verilmiştir.

Tablo 1. Su Ayak İzi Ağı soruları

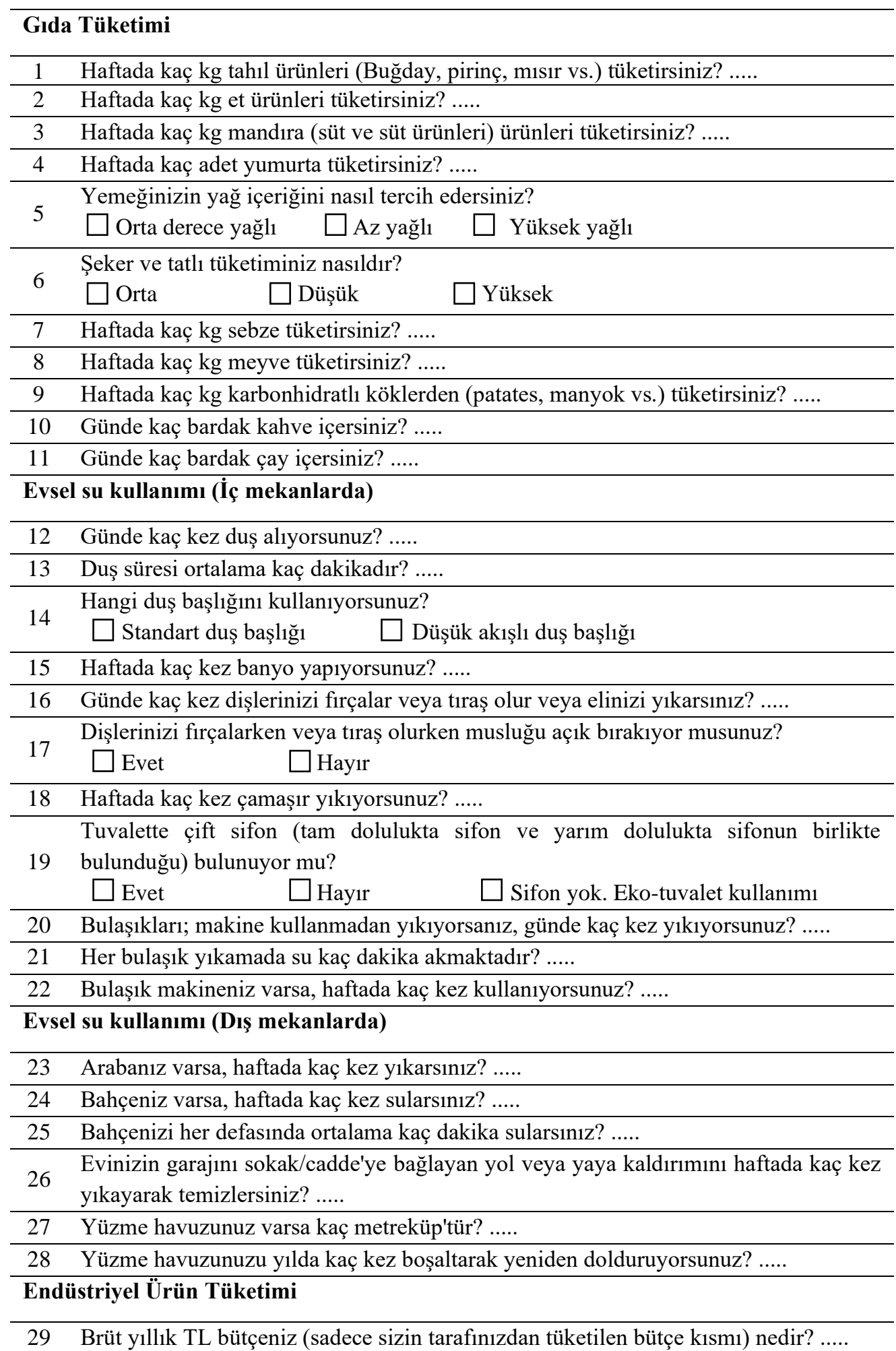




\section{Bulgular}

$\mathrm{Su}$ ayak izi ağı hesaplama motoruna katılımcıların cevapları işlenmiş ve Ardahan Üniversitesi Yenisey Kampüsü personel ve öğrencilerinin su ayak izleri hesaplanmıştır. Elde edilen bulgular aşağıda üç başlıkta kapsamlı olarak değerlendirilmiştir.

\subsection{Gıda tüketimi}

İnsan ihtiyaçlarının temeli olan gıda tüketimi ile, insan faaliyetleri ve toprak arasinda doğrudan ilişki vardır. Besin tüketimi, sadece besin kaynaklarına bağlı olmamakta, aynı zamanda besin tedarik zinciri boyunca enerji, toprak ve su gibi diğer doğal kaynaklara da bağlıdır (FAO, 2013; Gustavsson vd., 2011). $\mathrm{Su}$ ayak izi, tüketici farkındalığı için iyi olmasına rağmen tüketicilerin farklı ürünler arasında seçim yapmasına yardımcı olmak için henüz etkili bir araç değildir. Zaman geçmesi, metodolojilerin gelişmesi ve daha standart hale gelmesiyle bu değişebilir. Veriler şimdilik, işletmelere ve diğer su kullanıcılarına su ortamı bağlamında nasıl en iyi şekilde çalışabileceklerinde yol gösterici olmaktadır (Water Footprinting Report, 2009). Lokal ve bölgesel seviyelerde su yönetim stratejileri ile yeterli g1da üretimi yapılarak gelecekteki talep karşılanabilir (Feng vd., 2012). Bu stratejilerin belirlenmesinde; bölgesel nüfus ve gelir artış1, şehirleşme ve sanayileşmede beklenen eğilimler dikkate alınarak araştırma, politika analizleri yapılmalı ve ayrıca bu eğilimlerdeki değişiklikleri yansıtan potansiyel seçenekler karşılaştırılmalıdır (Renault ve Wallender, 2000; Rockström vd., 2009).

Gıda tüketimi alanı 11 sorudan oluşmaktadır. Bu sorulardan 5 ve 6 numaralı sorular kapalı uçlu, diğer sorular ise açık uçlu olarak katılımcılara yöneltilmiştir. 1 numaralı soru "Haftada kaç kg tahıl ürünleri (Buğday, pirinç, misır vs.) tüketirsiniz?" olarak yöneltilmiş ve ortalama $1.46 \mathrm{~kg}$ tahıl tüketimi olduğu saptanmıştır. 2 numaralı soru "Haftada kaç kg et ürünleri tüketirsiniz?" olarak yöneltilmiş ve ortalama $1.37 \mathrm{~kg}$ et tüketimi olduğu saptanmıştır. 3 numaralı soru "Haftada kaç kg mandira (süt ve süt ürünleri) ürünleri tüketirsiniz?" olarak yöneltilmiş ve ortalama $1.95 \mathrm{~kg}$ mandıra ürünleri tüketimi olduğu saptanmıştır. 4 numaralı soru "Haftada kaç adet yumurta tüketirsiniz?" olarak yöneltilmiş ve ortalama 8.67 adet yumurta tüketimi olduğu saptanmıştır. 7 numaralı soru "Haftada kaç kg sebze tüketirsiniz?" olarak yöneltilmiş ve ortalama $2.14 \mathrm{~kg}$ sebze tüketimi olduğu saptanmıştır. 8 numaralı soru "Haftada kaç kg meyve tüketirsiniz?" olarak yöneltilmiş ve ortalama $2.21 \mathrm{~kg}$ meyve tüketimi olduğu saptanmıştır. 9 numaralı soru "Haftada kaç kg karbonhidratlı köklerden (patates, manyok vs.) tüketirsiniz?" olarak yöneltilmiş ve ortalama $2.04 \mathrm{~kg}$ karbonhidrat köklü gıda tüketimi olduğu saptanmıştır. 10 numaralı soru "Günde kaç bardak kahve içersiniz?" olarak yöneltilmiş ve ortalama 1.57 bardak kahve tüketimi olduğu saptanmıştır. 11 numaralı soru "Günde kaç bardak çay içersiniz?" olarak yöneltilmiş ve ortalama 6.57 bardak çay tüketimi olduğu saptanmıştır. 
Tablo 2. Gıda tüketim alanında açık uçlu soruların ortalamas1

\begin{tabular}{cccc}
\hline \multicolumn{4}{c}{ Gıda Tüketimi Su Ayak İzi Ağ1 } \\
\hline $\begin{array}{c}\text { Su Ayak } \\
\text { İzi Ağ1 } \\
\text { Soruları }\end{array}$ & Personel & Öğrenci & $\begin{array}{c}\text { Personel + } \\
\text { Öğrenci }\end{array}$ \\
1 & $1.54 \mathrm{~kg}$ & $1.37 \mathrm{~kg}$ & $1.46 \mathrm{~kg}$ \\
2 & $1.34 \mathrm{~kg}$ & $1.40 \mathrm{~kg}$ & $1.37 \mathrm{~kg}$ \\
3 & $2.15 \mathrm{~kg}$ & $1.74 \mathrm{~kg}$ & $1.95 \mathrm{~kg}$ \\
4 & 8.9 & 8.43 & 8.67 \\
7 & $2.02 \mathrm{~kg}$ & $2.25 \mathrm{~kg}$ & $2.14 \mathrm{~kg}$ \\
8 & $2.23 \mathrm{~kg}$ & $2.19 \mathrm{~kg}$ & $2.21 \mathrm{~kg}$ \\
9 & $1.74 \mathrm{~kg}$ & $2.33 \mathrm{~kg}$ & $2.04 \mathrm{~kg}$ \\
10 & 1.4 & 1.73 & 1.57 \\
11 & 7.60 & 5.54 & 6.57 \\
\hline
\end{tabular}

Katılımcılara, 5 numaralı soru "Yemeğinizin yă̆ içeriğini nasıl tercih edersiniz?" olarak yöneltilmiş ve Şekil 2'de verildiği üzere \% 45 'i (144 kişi) orta derece yağl1, \% 50'si (161 kişi) az yağlı, \% 5'i (15 kişi) ise yüksek yağlı yemeği tercih ettiğini beyan etmiştir. 6 numaralı soru "Şeker ve tatlı tüketiminiz nasıldır?" olarak yöneltilmiş ve Şekil 3'te verildiği üzere katılımcılar şeker/tatlı tüketimini \% 47'si (151 kişi) orta, \% 33'ü (105 kişi) düşük, \% 20'si (64 kişi) ise yüksek olarak beyan etmiştir.

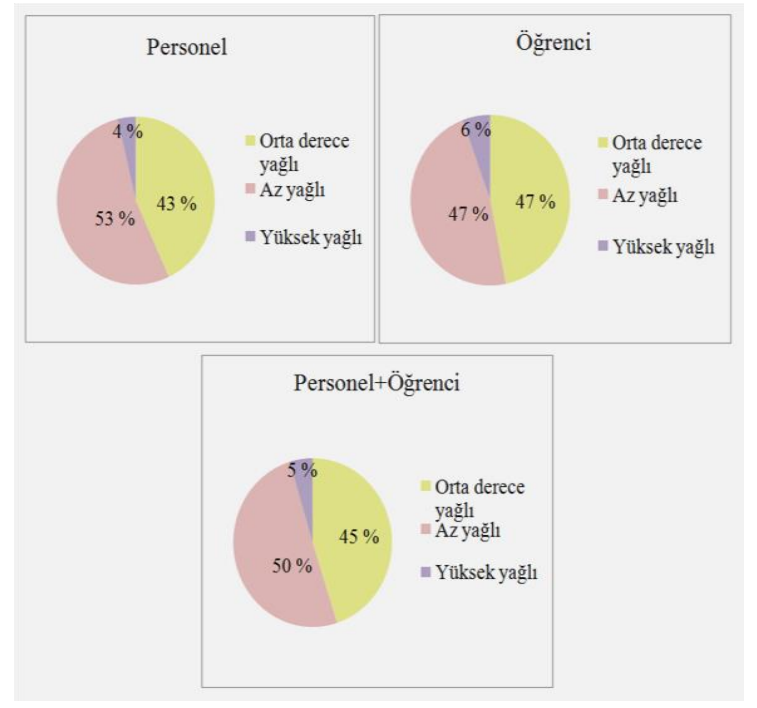

Şekil 2. Yemek yağ içeriği tercih oranı

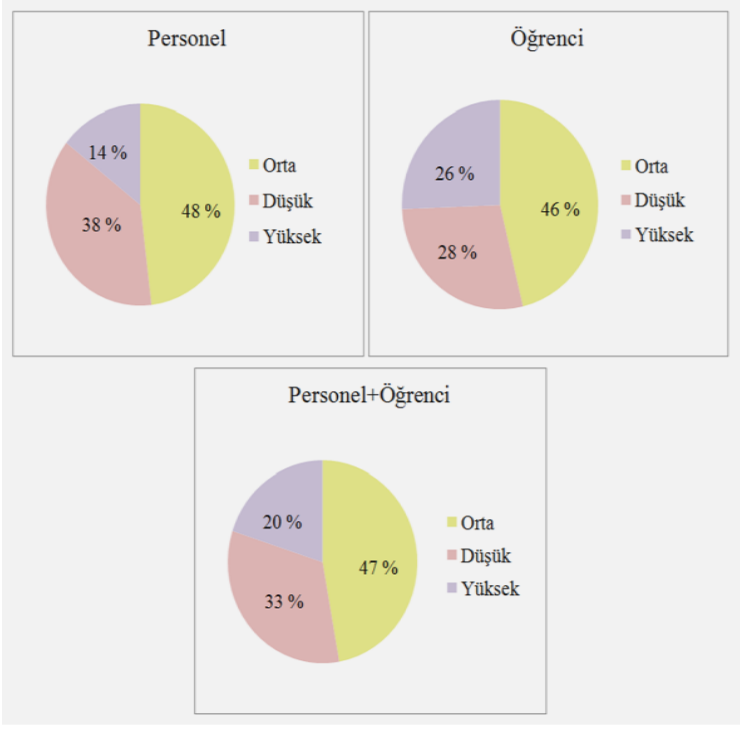

Şekil 3. Şeker ve tatlı tüketimi tercih oranı

\subsection{Evsel su kullanımı (İç ve dış mekanlarda)}

İç mekanlarda evsel su kullanımı 11 soru ve dış mekanlarda evsel su kullanımı ise 6 sorudan oluşmaktadır. İç mekanlarda evsel su kullanımında 14,17 ve 19 numaralı sorular kapalı uçlu, diğer sorular ise açık uçludur. Dış mekanlarda evsel su kullanımında ise, sorular açık uçludur. 12 numaralı soru "Günde kaç kez duş alıyorsunuz?" olarak yöneltilmiş ve ortalama $0.99 \mathrm{kez}$ duş alındığı saptanmıştır. 13 numaralı soru "Duş süresi ortalama kaç dakikadır?" olarak yöneltilmiş ve ortalama 21.55 dak olduğu saptanmıştır. 15 numaralı soru "Haftada kaç kez banyo yapıyorsunuz?" olarak yöneltilmiş ve ortalama $2.32 \mathrm{kez}$ banyo yapıldığı saptanmıştır. 16 numaralı soru "Günde kaç kez dişlerinizi firçalar veya tıraş olur veya elinizi yıkarsınız?" olarak yöneltilmiş ve üç kategori toplamı dikkate alınarak ortalama $5.08 \mathrm{kez}$ olduğu saptanmıştır. 18 numaralı soru "Haftada kaç kez çamaşır yıkıyorsunuz?" olarak yöneltilmiş ve ortalama $2.50 \mathrm{kez}$ çamaşır yıkandığı saptanmıştır. 20 numaralı soru "Bulaşıkları; makine kullanmadan yıkıyorsanız, günde kaç kez yıkıyorsunuz?" 
olarak yöneltilmiş ve ortalama $1.63 \mathrm{kez}$ yıkandığı saptanmıştır. 21 numaralı soru "Her bulaşık yıkamada su kaç dakika akmaktadır?" olarak yöneltilmiş ve ortalama 10.84 dak su aktı̆̆1 saptanmıştır. 22 numaralı soru "Bulaşık makineniz varsa, haftada kaç kez kullanıyorsunuz?" olarak yöneltilmiş ve ortalama $2.25 \mathrm{kez}$ makine ile yıkama yapıldığ saptanmıștır. 23 numaralı soru "Arabanız varsa, haftada kaç kez yıkarsınız?" olarak yöneltilmiş ve ortalama $0.56 \mathrm{kez}$ araba yıkaması yapıldığı saptanmıştır. 24 numaralı soru "Bahçeniz varsa, haftada kaç kez sularsınız?" olarak yöneltilmiş ve ortalama $0.68 \mathrm{kez}$ sulama yapıldığı saptanmıştır. 25 numaralı soru "Bahçenizi her defasında ortalama kaç dakika sularsınız?" olarak yöneltilmiş ve ortalama 6.48 dak sulama yapıldığı saptanmıştır. 26 numaralı soru "Evinizin garajını sokak/cadde'ye bağlayan yol veya yaya kaldırımını haftada kaç kez yıkayarak temizlersiniz?" olarak yöneltilmiş ve ortalama $0.52 \mathrm{kez}$ y1kama yapıldığ 1 saptanmıştır. 27 numaralı soru "Yüzme havuzunuz varsa kaç metreküp'tür?" olarak yöneltilmiş ve ortalamanın $0.39 \mathrm{~m}^{3}$ olduğu saptanmıştır. 28 numaralı soru "Yüzme havuzunuzu yılda kaç kez boşaltarak yeniden dolduruyorsunuz?" olarak yöneltilmiş ve ortalama $0.31 \mathrm{kez}$ doldurulduğu saptanmıştır.

Tablo 3. İç ve dış mekanlarda evsel su kullanımı alanında açık uçlu soruların ortalaması

Evsel Su Kullanımı (İç ve Dış Mekanlarda) Su Ayak İzi A $\breve{g}_{1}$

\begin{tabular}{cccc}
\hline $\begin{array}{c}\text { Su Ayak } \\
\text { İzi Ağ1 } \\
\text { Soruları }\end{array}$ & Personel & Öğrenci & $\begin{array}{c}\text { Personel + } \\
\text { Öğrenci }\end{array}$ \\
12 & 0.87 & 1.10 & 0.99 \\
13 & 18.4 dak & 24.7 dak & 21.55 dak \\
15 & 2.74 & 1.89 & 2.32 \\
16 & 6.75 & 3.41 & 5.08 \\
18 & 2.55 & 2.44 & 2.50 \\
20 & 1.25 & 2.0 & 1.63 \\
21 & 9.48 dak & 12.19 dak & 10.84 dak \\
\hline
\end{tabular}

\begin{tabular}{cccc}
\hline 22 & 2.75 & 1.74 & 2.25 \\
23 & 0.62 & 0.50 & 0.56 \\
24 & 0.58 & 0.77 & 0.68 \\
25 & $5.29 \mathrm{dak}$ & $7.67 \mathrm{dak}$ & $6.48 \mathrm{dak}$ \\
26 & 0.29 & 0.75 & 0.52 \\
27 & $0.44 \mathrm{~m}^{3}$ & $0.34 \mathrm{~m}^{3}$ & $0.39 \mathrm{~m}^{3}$ \\
28 & 0.14 & 0.48 & 0.31 \\
\hline
\end{tabular}

Katılımcılara, 14 numaralı soru "Hangi duş başlığını kullanıyorsunuz?" olarak yöneltilmiş ve Şekil 4'te verildiği üzere \% 81'i (259 kişi) standart duş başlığı, \% 19'u (61 kişi) düşük akışlı duş başlığı tercih ettiğini beyan etmiştir. 17 numaralı soru "Dişlerinizi fırçalarken veya tıraş olurken musluğu açık bırakıyor musunuz?" olarak yöneltilmiş ve Şekil 5'te verildiği üzere \% 30'u (96 kişi) evet, \% 70'i (224 kişi) hayır olarak beyan etmiştir. 19 numaralı soru ise "Tuvalette çift sifon (tam dolulukta sifon ve yarım dolulukta sifonun birlikte bulunduğu) bulunuyor mu?" olarak yöneltilmiş ve katılımcıların tamamı hayır olarak beyanda bulunmuştur.

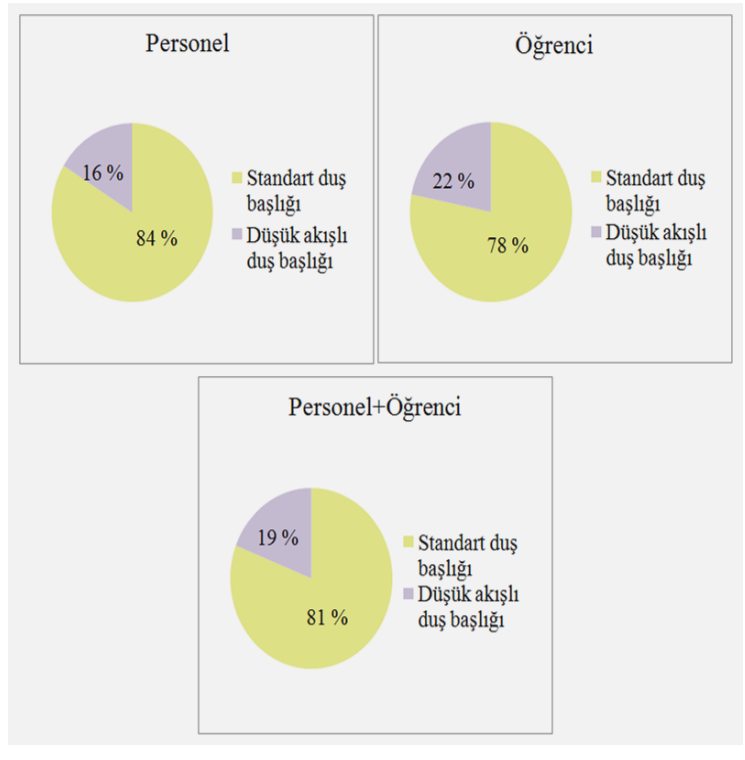

Şekil 4. Duş başlı̆ğ tercih oranı 


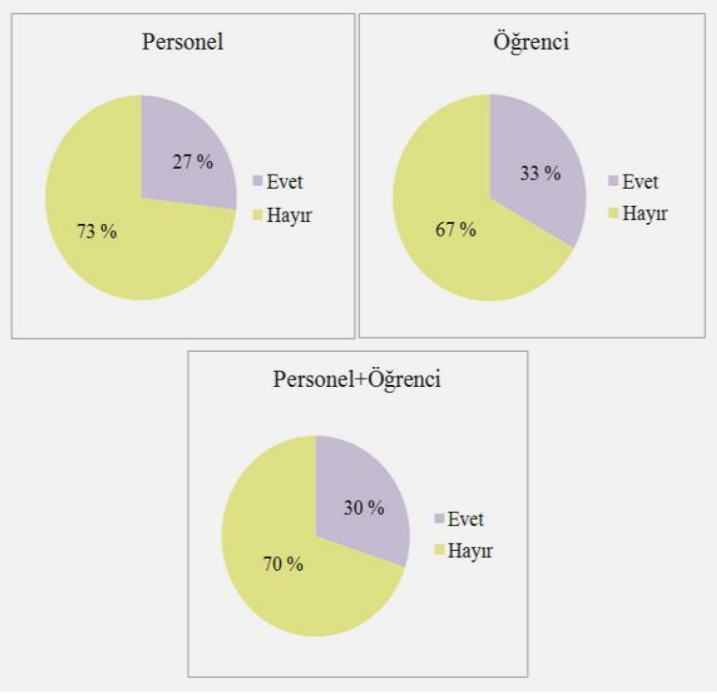

Şekil 5. "Dişlerinizi firçalarken veya tıraş olurken musluğu açık bırakıyor musunuz?" sorusunda yanıtların dağılımı

\subsection{Endüstriyel ürün tüketimi}

Endüstriyel ürün tüketimi 1 açık uçlu sorudan oluşmaktadır. 29 numaralı soru "Brüt y1llık TL bütçeniz (sadece sizin tarafinızdan tüketilen bütçe kısmı) nedir?" olarak yöneltilmiş ve ortalamanın 13.058,4 TL olduğu saptanmıştır. Bu soru Su Ayak İzi Ağı'nda, para birimi olarak US\$ türünde sorulduğundan, 18 Mayıs 2019 tarihli US\$ kuruna göre hesaplama yapılmıştır.

Tablo 4. Endüstriyel ürün tüketimi alanında açık uçlu sorunun ortalaması

Endüstriyel Ürün Tüketimi Su Ayak İzi Ağ̀

\begin{tabular}{cccc}
\hline $\begin{array}{c}\text { Su Ayak } \\
\text { İzi Ağ1 } \\
\text { Sorusu }\end{array}$ & Personel & Öğrenci & $\begin{array}{c}\text { Personel + } \\
\text { Öğrenci }\end{array}$ \\
29 & $17.581,4 \mathrm{TL}$ & $8.535,4 \mathrm{TL}$ & $13.058,4 \mathrm{TL}$ \\
\hline
\end{tabular}

\section{Sonuçlar}

$\mathrm{Su}$ kaynakları sürdürülebilir olarak yönetilemezse, dünya nüfusunda artış1 desteklemek ve çevresel ihtiyaçları karşılamak için yeterli su temininde büyük zorluklarla karşılaşılabilir. Dünyada hemen her yerde, geçmişten günümüze kadar suyun sürdürülebilir bir şekilde yönetilmesi ile ilgili bir takım yollar izlenmiştir ancak, izlenmiş olan bu yollar yetersiz kalmıştır. Bu nedenle, son yıllarda mevzuatlar ve su verimliliği teknolojisinde önemli adımlar atılmış olmasına rağmen, su kıtlığı ve su kirliliği çok yaygin olarak devam etmektedir. Arjen Y. Hoekstra ve ekibi sürdürülebilir su kullanımı için su ayak izi kavramını oluşturmuştur. Su ayak izi; hammaddelerin işlenmesinden, tüketicilerin ürünü kullanmasına kadar geçen tüm süreci kapsamaktadır. Böylece, su ayak izi ile hem doğrudan su kullanımı hem de üretim sürecinde dolaylı su kullanımı hesaba katılmaktadır. Kampüs suyunun su ayak izi bileşenleri, su kaynağı ve su ayak izi ağ1 sorularına göre irdelenebilir. Kampüse suyu sağlayan kaynak mavi su ayak izini, su kullanımı sonucu oluşan tatlı su kirliliğinin su kalite standartlarına göre kirletici yükünü azaltılması için gerekli olan tatlı su hacmi gri su ayak izini, su ayak izi ağının gıda tüketim alanındaki ürünlerin üretim aşamasındaki su kullanımı ise yeşil su ayak izini kapsamaktadır.

Su ayak izi ağ1 hesaplama motoruna göre, Ardahan Üniversitesi Yenisey Kampüsü personel ve öğrenci su ayak izi sırasıyla $1420.4 \mathrm{~m}^{3} / \mathrm{y} 1 \mathrm{l}$ ve $1490.1 \mathrm{~m}^{3} / \mathrm{y} 1 \mathrm{l}$ olarak belirlenmiştir. Personel su ayak izi bileşenlerinin Şekil 6'da verildiği üzere \% 80'ini gıda tüketim alanı, \% 15'ini iç ve diş mekanlarda evsel su kullanım alanı, \% 5'ini ise endüstriyel ürün tüketim alanı oluşturmaktadır. Bu oranların gıda tüketimi, iç ve dış mekanlarda evsel su kullanımı, endüstriyel ürün tüketimi alanlarında su tüketim miktarı dağılımı sirasıyla 1129.9 $\mathrm{m}^{3} / \mathrm{y} 1 \mathrm{l}, 217.3 \mathrm{~m}^{3} / \mathrm{y} 1 \mathrm{l}$ ve $73.2 \mathrm{~m}^{3} / \mathrm{y} 1 \mathrm{l}$ olarak saptanmıştır. Öğrencilerin su ayak izi bileşenlerinin Şekil 6 'da verildiği üzere \% 77'sini gıda tüketim alanı, \% 21'ini iç ve dış 
mekanlarda evsel su kullanım alanı, \% 2'sini ise endüstriyel ürün tüketim alanı oluşturmaktadır. Bu oranların gıda tüketimi, iç ve dış mekanlarda evsel su kullanımı ve endüstriyel ürün tüketimi alanlarında su tüketim miktarı dağılımı sırasıyla 1140.7 $\mathrm{m}^{3} / \mathrm{y} 1 \mathrm{l}, 312.3 \mathrm{~m}^{3} / \mathrm{y} 1 \mathrm{l}$ ve $37.0 \mathrm{~m}^{3} / \mathrm{y} 1 \mathrm{l}$ olarak saptanmıştır. Literatürde, "Su ayak izi ağı" kullanılarak su ayak izi hesaplaması ile ilgili araştırmaya rastlanmamış olup, sonuçların "Su ayak izi ağı" kullanılarak yapılacak olan araştırmalara katkı sağlayacağ öngörülmektedir. Kampüs su ayak izinin belirlenmesi üzerine farklı uygulamalar kullanılarak sınırlı sayıda çalışma yapılmıştır. $\mathrm{Bu}$ araştırmalardan biri Natyzak vd. (2017) tarafindan yapılmış olup, University of Virginia (UVA)'nın su ayak izini doğrudan su kullanımı ve sanal su kullanımı toplamı olarak hesaplamıştır. Water Footprint Statistics (WaterStat) ile değerlendirilerek üniversite bünyesindeki kamu hizmetleri, gıda, ulaşım, kağıt, araştırma hayvanları ve hastane satın alımları için satın alma kayıtlarını içeren tesis yönetimi su faturaları rapor edilmiş ve su ayak izi tahmin edilmiștir. Toplam su ayak izinin; \%10.06'sını doğrudan su kullanımı, \% 45.77'sini kamu hizmeti sektörü, \% 23.34'ünü gıda üretim sektörü, \% 16.88 'ini sağlik sektörü, \% 3.95'ini ise kağıt, ulaşım ve araştırma hayvanları alanı oluşturmuştur. Ayak izinin doğrudan su kullanımı kısmı 1,7 milyon $\mathrm{m}^{3}$, sanal su ayak izi ise 15,2 milyon $\mathrm{m}^{3}$ olarak belirlenmiştir. Başka bir araştırma ise, Allison vd. (2018) tarafindan Emory Üniversitesi'nde yapılmıştır. Bu araştırmada ise, kampüs çapında yenilikçi su ıslahı için WaterHubt olarak bilinen yeniden kullanım sistemi devreye alınmıştır. $\mathrm{Bu}$ sistem ile günlük 151 litre geri kazanım sağlanarak üniversite'nin atık su üretimi üçte ikisi eşdeğerine geri dönüştürülmüş, böylece kampüs su ayak izi \% 40'a kadar azaltılmıştır.

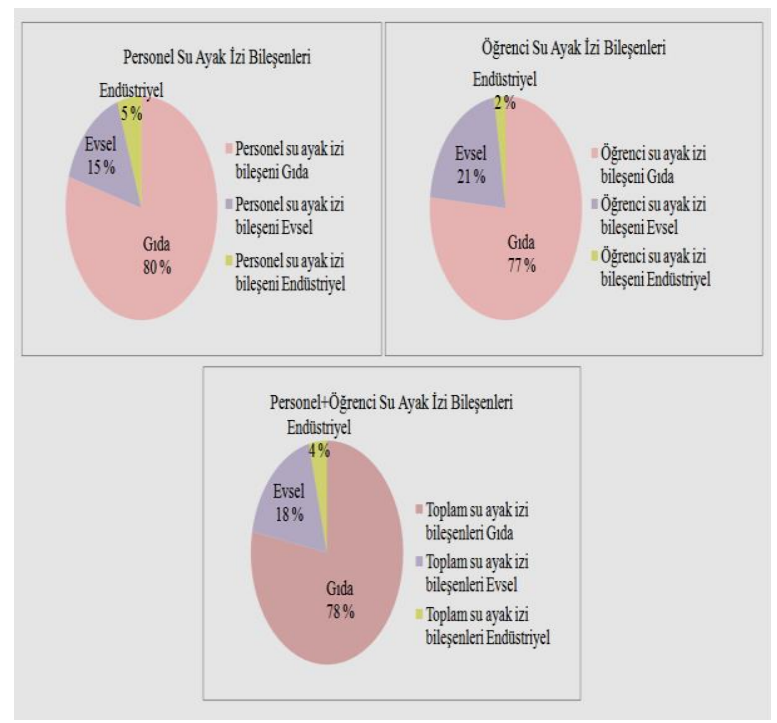

Şekil 6. Ardahan Üniversitesi Yenisey Kampüsü su ayak izi bileşenlerinin oranı

Su ayak izi ağındaki sorular, katılımcılar tarafından yıl içindeki genel alışkanlıkların ortalama değerleri göz önünde bulundurularak cevaplandırılmıştır. $\mathrm{Bu}$ durum genel olarak değerlendirildiğinde, Ardahan ili, yılda ortalama dokuz ay yağış alan bir bölge olduğundan, anket katılımcıları sorulara kış mevsimi bazlı ortalama değerlerde alışkanlıklara göre cevap vermiştir. Ardahan ilinin yoğun yağış alan bir bölge olması doğrudan su kullanımında (duş alma, banyo yapma, bahçe sulama, araba yıkama say1s1/süresi vs.) azaltıcı etkide olup, yaz mevsiminin yoğun yaşandığı bölgelerde bu araştırmanın yapılması durumunda doğrudan su kullanımında artış olacağ düşünülmektedir.

Tarımda yağış seviyesinin sulama ihtiyacı üzerinde doğrudan bir etkisi vardır. Bazı gelişmekte olan ülkelerde, sulama doğal kaynaklardan alınan suyun \% 90'ından fazlasını oluşturmaktadır (Water Footprinting Report, 2009). Bu çalışmada su ayak izi ağına göre, Ardahan Üniversitesi Yenisey Kampüsü su ayak izi $1455.2 \mathrm{~m}^{3} / \mathrm{y} 1 \mathrm{l}$ olarak belirlenmiştir. Su ayak izi bileşenlerinin Şekil 6'da verildiği üzere \% 78'ini gıda tüketim alanı, \% 18'ini iç 
ve dış mekanlarda evsel su kullanım alanı, \% 4'ünü ise endüstriyel ürün tüketim alanı oluşturmaktadır. Bu oranların gıda tüketimi, iç ve diş mekanlarda evsel su kullanımı ve endüstriyel ürün tüketimi alanlarında su tüketim miktarı dağılımı ise sırasıyla 1135.3 $\mathrm{m}^{3} / \mathrm{y} 1 \mathrm{l}, 264.8 \mathrm{~m}^{3} / \mathrm{y} 1 \mathrm{l}$ ve $55.1 \mathrm{~m}^{3} / \mathrm{y} 1 \mathrm{l}$ olarak saptanmıştır. Araştırmada, \% 78 olarak belirlenmiş gıda tüketim alanı oranı, su ayak izi araştırmalarının büyük çoğunluğunda belirtilmiş olan en yüksek su kullanım alanının tarımsal sulamadan kaynaklı olduğu değerlendirmelerini desteklemektedir.

Suyun kampüste kullanım alanlarının neredeyse tamamını içme-kullanma suyu oluşturmakta ve sürdürülebilirliği değerlendirildiğinde:

Su kaynağı: Kampüs'ün suyu, Çamlıçatak köyü mevkii'nde bulunan yer altı su kuyusundan temin edilmektedir. Yeraltı su kaynaklarında kirliliğinin temizlenmesinin zor ve maliyetli olması göz önünde bulundurularak, bu su kaynağının çevresi koruma altına alınmıştır. Böylece, kullanmaya uygun olmayan düşük kalitedeki suların karışması, antropojenik ve hayvansal kaynaklı etkilerle kimyasal-mikrobiyal kirlenmelerin önlenmesi amaçlanmıştır. Ardahan ili, çoğunlukla yağış (kar, yağmur) alan bir bölge olduğundan mevcut su kaynağının sürdürülebilir olacağ 1 öngörülmektedir. Gerekli görüldüğü takdirde, alternatif yer altı su kuyuları açılabilir.

Verimli peyzaj sulama: Kampüs su kullanımının nispeten çok küçük bir bölümünü temsil etmektedir. Çevre düzenlemesi için ekim seçenekleri ve bakım rejimlerinin sulama suyu talebinde önemli bir etkisi olabilir ancak, Ardahan ilinin genel olarak yıl boyunca yağışlı olması peyzaj sulamasını daha az gerektirmektedir.
Yağmur suyu toplama: Yağmur suyunun yeniden kullanımı, bir yağmur suyu toplama sistemini gerektirdiğinden ve suyun değerine kıyasla son derece pahalı olduğundan şu anda finansal olarak mümkün görünmemektedir.

Diğer: Kampüste endüstriyel ürün üretimi yapılmaması, iklim şartlarından dolayı tarımsal faaliyet (hobi bahçesi) yapılmaması, su sporlarına yönelik faaliyetlerin aktif olmaması da suyun doğrudan kullanımında azaltıcı etki göstermiştir.

\section{5. Öneriler}

Su kıtlığının küresel bir zorluk olduğu göz önünde bulundurularak su tüketimi bilinçli yapılmalıdır. Su tüketimi, en çok tarımsal sulamadan kaynaklanmaktadır. Tarımsal su kullanımında su tasarrufu çok fazla yapılamayabilir ancak, evsel su kullanımında su tasarrufu mümkün olduğunca yapılabilir. Evsel su kullanımında tüketiciler, su tasarrufu sağlayan duş başlığı ve tuvalet kullanımı başta olmak üzere, diş firçalama sırasında musluğu kapatarak, bahçede daha az su kullanarak, boya, yă̆ atıkları ve diğer kirleticileri lavabolara dökmeyerek su ayak izlerini azaltabilirler.

\section{Kaynaklar}

Allison, D., Lohan, E., Baldwin, T. 2018. "The WaterHub at Emory University: Campus Resiliency through Decentralized Reuse", Water Environment Research, February, 187192.

Cao, X., Wu, M., Zheng, Y., Guo, X., Chen, D., Wang, W. 2018a. "Can China achieve food security through the development of irrigation?", Regional Environmental Change, 18(2), 465-475.

Cao, X., Ren, J., Wu, M., Guo, X., Wang, Z., Wang, W. 2018b. "Effective use rate of generalized water resources assessment and to improve agricultural water use efficiency 
evaluation index system", Ecological Indicators, 86, 58-66.

FAO, 2013. "Food Wastage Footprint: Impacts on Natural Resources. Summary Report",http://www.fao.org/3/i3347e/i3347e. pdf, Son erişim tarihi: 03.06.2019

Feng, K., Siu, Y.L., Guan, D., Hubacek, K. 2012. "Assessing regional virtual water flows and water footprints in the Yellow River Basin, China: A consumption based approach", Applied Geography, 32 (2), 691701.

Gustavsson, J., Cederberg, C., Sonesson, U., Otterdijk, R., Van Meybeck, A. 2011. "Global Food Losses and Food Waste: Extent, Causes and Prevention", FAO, Rome, http://www.fao.org/3/a-i2697e.pdf, Son erişim tarihi: 03.06.2019

Hoekstra, A.Y., Chapagain, A.K., Aldaya, M.M., Mekonnen, M.M. 2011. The Water Footprint Assessment Manual, Setting the Global Standard, Water Footprint Network, London, Washington DC.

Hoekstra, A.Y., Mekonnen, M.M. 2012. "The water footprint of humanity", Proceedings of the National Academy of Sciences (PNAS), 109(9), 3232-3237.

Mekonnen, M.M., Hoekstra, A.Y. 2016. "Four billion people facing severe water scarcity", Science Advances, 2 (2) DOI: 10.1126/sciadv.1500323.

Natyzak, J.L., Castner, E.A., D’Odorico, P., Galloway, J.N. 2017. "Virtual Water as a Metric for Institutional Sustainability", Sustainability, 10 (4), 237-245.

Renault, D., Wallender, W.W. 2000. "Nutritional water productivity and diets", Agricultural Water Management, 45, 275296.

Rockström, J., Falkenmark, M., Karlberg, L., Hoff, H., Rost, S., Gerten, D. 2009. "Future water availability for global food production: The potential of green water for increasing resilience to global change", Water Resources Research, 45, 1-16.
Schewe, J., Heinke, J., Gerten, D., Haddeland, I., Arnell, N.W., Clark, D.B., Dankers, R., Eisner, S., Fekete, B.M., ColónGonzález, F.J., Gosling, S.N., Kim, H., Liu, X., Masaki, Y., Portmann, F.T., Satoh, Y., Stacke, T., Tang, Q., Wada, Y., Wisser, D., Albrecht, T., Frieler, K., Piontek, F., Warszawski, L., Kabat, P. 2014. "Multimodel assessment of water scarcity under climate change", Proceedings of the National Academy of Sciences (PNAS), 111(9), 32453250 .

Water Footprint Network. "Personal water pootprint calculator", https://waterfootprint.org/en/resources/intera ctive-tools/personal-water-footprint calculator/personal-calculator-extended/, Son erişim tarihi: 29.05.2019

Water Footprinting Report, 2009. Identifying \& Addressing water risks in the value chain, SABMILLER, WWF.

Vörösmarty, C.J., Green, P., Salisbury, J., Lammers, R.B. 2000. "Global water resources: Vulnerability from climate change and population growth", Science, 289(5477), 284-288. 